\title{
PROGRESS IN RESEARCH ON BREEDING FOR RESISTANCE TO SUNFLOWER BROOMRAPE*
}

Fernández-Martínez, J.M. ${ }^{* *}$, Velasco, L. and Pérez-Vich, B.

Instituto de Agricultura Sostenible (IAS-CSIC).

Alameda del Obispo s/n, 14004 Córdoba, Spain

Received: October 23, 2012

Accepted: December 01, 2012

SUMMARY

Sunflower broomrape (Orobanche cumana Wallr.) is a parasitic angiosperm regarded as one of the most serious production constraints in many sunflower-producing countries. Historically, sunflower breeders have been successful in developing cultivars resistant to this parasite, but the introduction of new resistance sources has been frequently followed by the appearance of new pathogenic races overcoming the resistance. The present review sets out to examine the principal achievements in this field that took place during the last decades, focusing on the most recent advances in the research. In recent years, several research groups have made relevant contributions in breeding for the resistance and the development of control strategies. Following the identification and characterization of new virulent races, new sources and mechanisms of resistance have been developed and characterized at the genetic and molecular level. There have been also important contributions to the knowledge of the biology and genetics of the parasite that will contribute to the understanding of the dynamics of broomrape populations and race evolution. Important advances have also been made in the use of imidazolinone (IMI)-resistant hybrids as an alternative method of control. Most of the studies on sunflower breeding for resistance to $O$. cumana have been concentrated so far on the host plant, but in spite of the recent advances little is known about the important aspects of the parasite side of the equation such as the breeding system and genetics of virulence. An unsolved problem is the existing uncertainty in the designation of races and resistance genes identified in different countries. There is a need for international cooperation in this area using common differentials and molecular tools. Emphasis is given to the need for a multidisciplinary approach ranging from studying the mechanisms underlying resistance in the host plant to the reproductive biology and genetics of traits related to parasitism in $O$. cumana. The combination of long term strategies involving the complete host-parasite system and the integration of classical and molecular approaches is expected to contribute to the development of more

* Paper from a Plenary Lecture at the $18^{\text {th }}$ International Sunflower Conference, Mar del Plata \& Balcarce, Argentina, 2012.

** Corresponding author: Tel: +34-957-499204; Fax: +34-957-499252;

e-mail: jfernandezm@ias.csic.es. 
durable sources of resistance and to improve sunflower performance in areas infested by broomrape.

Key words: broomrape races, genetic resistance, herbicide tolerance, Helianthus annuus, Orobanche cumana, sunflower

\section{INTRODUCTION}

Sunflower broomrape (Orobanche cumana Wallr.) is a holoparasitic plant that currently represents one of the most serious production constraints in many sunflower-producing countries around the world, especially in Central and Eastern Europe, Spain, Turkey, Israel, Iran, Kazakhstan, and China (Škorić et al., 2010). Broomrape attacks are frequently severe and yield losses can reach up to $50 \%$ (Domínguez, 1996a). Historically, sunflower breeders have been successful in developing broomrape resistant cultivars, but breeding programs are often based on a reduced number of dominant genes and resistance breakdown caused by the appearance of new virulent races that overcome all known resistance genes has frequently occurred in the last decades (Fernández-Martínez et al., 2008). This situation has forced sunflower breeders to continuously search for new sources of resistance and / or use alternative methods of control such as the use of imidazolinone (IMI)-resistant hybrids. The aim of this review is to discuss recent advances in research in the development and genetic characterization of new sources of resistance to new virulent races, as well as in the biology and genetics of the parasite and in the development of IMI- resistant hybrids.

\section{Reproductive biology of the parasite}

Studies on sunflower resistance to $O$. cumana have been mainly concentrated on understanding the mechanisms underlying resistance in the host plant, but little is known about the parasite side of the picture. There is scarce information about the reproductive biology of the parasite, the genetic structure of the populations and the mode of inheritance of traits related to parasitism. Recently, a methodological study was conducted to test the feasibility of bagging $O$. cumana plants to produce seed from self-fertilization and controlled hybridization. The results revealed that O. cumana is self-compatible and tolerates seed production under isolation, both under self-fertilization as well as in controlled hybridization, although the bag type used for isolation clearly determined seed production. Best results were obtained for plants isolated with micro-perforated transparent plastic bags, which produced seeds that did not differ in germination and infectivity capacity from those produced in unbagged control plants (Rodríguez-Ojeda et al., 2010). Using these techniques, an unpigmented mutant lacking anthocyanin was isolated and the inheritance of the trait was studied in crosses with normal pigmented plants followed by evaluation of the $\mathrm{F}_{1}, \mathrm{~F}_{2}$ and $\mathrm{F}_{3}$ plant generations. The results revealed that the unpigmented trait was controlled by partially recessive alleles at a single locus, 
with the $\mathrm{F}_{1}$ hybrid being phenotypically distinguishable from both pigmented and unpigmented parents (Rodríguez-Ojeda et al., 2011). The feasibility of identifying phenotypically $F_{1}$ plants from unpigmented mutant plants has encouraged the use of the mutant as a phenotypic marker for estimating the rate of natural cross-fertilization in O. cumana, which was found to be between 14.8 and $40.0 \%$ in two separate experiments (Rodríguez-Ojeda et al., 2012). These results partially contradict the hypothesis of Gagne et al. (1998), who, based on the low intra-population variability detected in $O$. cumana populations, suggested that $O$. cumana is a self-pollinated species.

\section{Dynamics of broomrape populations and race evolution}

In the wild, O. cumana mainly parasitizes Artemisia spp., but shortly after the expansion of sunflower cultivation in Russia at the end of the 19th century $O$. cumana started parasitizing this crop as well (Vrânceanu et al., 1986). Genetic resistance was initially introduced into susceptible sunflower mainly from the wild species H. tuberosus (Škorić et al., 2010). However, new pathogenic races overcoming resistant cultivars appeared. In a classical study on the host-parasite system sunflower-Orobanche, Vrânceanu et al. (1980) indicated that it followed the genefor-gene model and identified five pathogenic races in Romania, named A through $\mathrm{E}$, with a set of sunflower differentials carrying the dominant resistance genes $\mathrm{Or}_{1}$ through $\mathrm{Or}_{5}$. A new virulent race named $\mathrm{F}$ overcoming resistance gene $\mathrm{Or}_{5}$ was identified in Spain in the mid-1990s (Alonso et al., 1996). Races overcoming all the known resistance genes to races $\mathrm{A}$ through $\mathrm{E}$ were also identified in other countries such as Romania, Turkey, Ukraine, Bulgaria and Russia. They have been named F, G, and H (Fernández-Martínez et al., 2008; Păcureanu-Joita et al., 2009; Škorić et al., 2010). However, no consistent comparative studies have been conducted on the virulence of broomrape populations from different countries overcoming $\mathrm{Or}_{5}$ resistance. Therefore, the current racial situation of broomrape in the main infested areas remains unclear, i.e., there is no information on whether races under the same classification reported in different countries are the same or differ for virulence. International cooperation to clarify the current racial status of sunflower broomrape using a collection of different races, common differential sets and molecular tools is becoming a top priority in sunflower research, taking particularly into account that broomrape is spreading into new areas such as some regions in Spain (Fernández-Escobar et al., 2009) and France (Jouffret and Lecomte, 2010).

In order to understand race evolution, a basic knowledge of the genetic structure and dynamics of $O$. cumana populations is required. Molecular studies on genetic diversity of sunflower broomrape concluded that there is low intra-population and large inter-population genetic variation with little gene exchange between regions (Gagne et al., 1998). However, the study of 38 old seed accessions of $O$. cumana in Spain provided evidence of heterogeneous populations with high virulence components (race F) in old populations collected prior to the identification of 
this race, suggesting selection pressure of resistance genes in these heterogeneous populations as a major evolutionary force building up new virulent races such as race $\mathrm{F}$ (Molinero-Ruiz et al., 2008). The high virulent components could be the result of recent mutation, but given the ease with which minuscule Orobanche seeds can be transferred from one place to another, they could have derived from seed introductions from other areas as reported in Spain (Fernández-Escobar et al., 2009). Genetic recombination may also play an important role in race evolution in $O$. cumana on account of the relatively high rate of outcrossing observed in this species, as mentioned in the previous section.

\section{Sources of resistance}

Unlike other host plant-Orobanche systems, sources of resistance to $O$. cumana in sunflower have been in most cases based on vertical resistance mechanisms, controlled by single dominant genes. This has led to a rapid breakdown of the resistance and subsequently to a continuous need for new resistance sources. In the early breeding sunflower work in the former USSR and Romania, sources of resistance to the first races were identified within landraces and also in the wild species, mainly H. tuberosus (Vrânceanu et al., 1980; Škorić et al., 2010). As new broomrape races were appearing, sources of resistance in the germplasm of cultivated sunflower became increasingly scarce, though valuable germplasm resistant to the latest races has still been identified, including germplasm with horizontal instead of vertical resistance (Fernández-Martínez et al., 2008; Păcureanu-Joita et al., 2009; Škorić et al., 2010). In contrast, a high level of resistance to the latest races has been found in wild Helianthus species. For example, an extensive evaluation of 54 wild accessions for resistance to several virulent races, including Spanish race $\mathrm{F}$, identified a high level of resistance in 29 perennial and four annual Helianthus species (Fernández-Martínez et al., 2000). The outstanding work carried out in Bulgaria over decades has produced a number of resistance sources to races from A to G from interspecific hybridization with 32 wild species (Christov et al., 2010). Recently, resistance to a race named $G$ has been transferred from $H$. debilis (Velasco et al., 2012). Transferring resistance genes from cultivated germplasm and wild annual species into elite germplasm can be accomplished rather easily by conventional crossing and backcrossing. Conversely, introgression of resistance from wild perennial species is generally more difficult due to problems associated with early hybrid embryo abortion and sterility in the $\mathrm{F}_{1}$ and $\mathrm{BC}_{1}$ generations and may require special techniques such as embryo rescue and chromosome doubling of the $\mathrm{F}_{1}$ (Jan and Fernández-Martínez, 2002).

\section{Characterization of resistance}

Several comprehensive reviews on inheritance of sunflower broomrape resist-

ance have been recently published (e.g. Fernández-Martínez et al., 2008; Škorić et al., 2010). Most genetic studies on different resistance sources to races A through $\mathrm{E}$ 
concluded that a major dominant gene conferred resistance to the latest race and to the previous ones (Vrânceanu et al., 1980; Sukno et al., 1999), even though other genetic mechanisms such as two dominant genes were also reported (Domínguez, 1996b). In contrast to races A though $\mathrm{E}$, initial genetic studies on resistance to race $\mathrm{F}$ concluded the presence of recessive alleles at two independent loci named $\mathrm{Or}_{6}$ and $\mathrm{Or}_{7}$ (Rodríguez-Ojeda et al., 2001; Akhtouch et al., 2002). Contrarily, PérezVich et al. (2002) found that resistance to race F in sunflower line $\mathrm{J} 1$ derived from wild species was controlled by dominant alleles at a single gene designated $\mathrm{Or}_{6}$. Further research revealed that dominance depended upon the susceptible parental line used for the cross, as in some cases $F_{1}$ hybrids segregated for resistance or were susceptible, which was attributed to the presence of a minor or modifying gene in some of the susceptible lines (Velasco et al., 2006). More recent studies on the inheritance of resistance to the latest races in several countries have concluded the presence of one or two dominant genes (Škorić et al., 2010; Velasco et al., 2012). Similarly to the problem of broomrape race nomenclature discussed above, no comparative genetic studies have been conducted on sunflower resistant germplasm developed by different authors, for which the same gene nomenclature $\mathrm{Or}_{6}$ and $\mathrm{Or}_{7}$ has been used.

Molecular studies aimed at mapping and tagging genes conferring resistance to races $\mathrm{E}$ and $\mathrm{F}$ have been carried out. These studies revealed that the $\mathrm{Or}_{5}$ gene conferring resistance to race $\mathrm{E}$ is located on a telomeric region of linkage group (LG) 3 of the sunflower genetic map (Lu et al., 2000; Tang et al., 2003; Pérez-Vich et al., 2004). The nature of this dominant gene is unknown, though it has been hypothesized that it might be a cluster of recognition-dependent resistance genes encoding proteins characterized by the presence of leucine-rich repeat (LRR) motifs and a nucleotide binding site (NBS) N-terminal to the LRR domain (Lu et al., 2000). This is supported by the mapping of three NBS-LRR loci to the upper segment of LG 3 closely linked to $\mathrm{Or}_{5}$, two of them derived from $\mathrm{H}$. tuberosus (Radwan et al., 2008), which has been extensively used as a source of broomrape resistance genes (Fernández-Martínez et al., 2008). Quantitative trait loci (QTL) analyses showed that, in addition to the major gene $\mathrm{Or}_{5}$, resistance to race $\mathrm{E}$ has also a quantitative component determined by four QTLs with minor effects, in some cases non-race specific and mainly associated with the number of broomrape stalks per plant (Pérez-Vich et al., 2004). The existence of this polygenic component in race $\mathrm{E}$ resistance is supported by histological observations and gene expression studies that demonstrated that several mechanisms such as reduced stimulation of broomrape seed germination or rapid necrosis at early stages of parasite development are involved in resistance to this broomrape race (Labrouse et al., 2001; Pérez de Luque et al., 2009). In contrast to race $\mathrm{E}$, molecular studies concluded that recessive resistance to race $\mathrm{F}$ in sunflower line P-96 was determined by six QTL, some of which were non-race specific and stable over environments (Pérez-Vich et al., 2004). Several resistance mechanisms to broomrape race $\mathrm{F}$ such as physical barriers involving cell wall 
suberization and protein cross-linking as well as chemical response by producing and secreting toxic compounds of a phenolic nature have been identified (Echevarría-Zomeño et al., 2006). In order to improve the durability of resistance, breeding strategies such as pyramiding major genes or combining vertical and horizontal resistance mechanisms must be implemented. In line with this, Hassan et al. (2011) reported the production of a strongly resistant hybrid from the combination of lines carrying two different resistant mechanisms, one of them consisting in the failure of inducing Orobanche seed germination (called system 1) and the other one consisting in the necrosis of the parasite structures at an early stage of development (called system 2).

\section{Use of herbicide-tolerant cultivars}

The rapid evolution of broomrape populations, which have shown strong capacity to overcome new resistance sources and to spread to new areas, induced sunflower breeders to consider alternative methods of broomrape control. The imidazolinone (IMI) family of herbicides controls weeds by inhibiting a key enzyme in the branched chain amino acid biosynthetic pathway, acetohydroxyacid synthase (Tan et al., 2005). In 1996, a wild sunflower population of $H$. annuus, highly tolerant to the IMI herbicide imazethapyr, was found in a soybean field in Kansas, U.S.A. (Al-Khatib et al., 1998). Seed specimens of this material were used by the USDA Agricultural Research Service at Fargo, ND to introgress genes underlying the herbicide tolerance into cultivated sunflower. Genetic stocks and breeding lines with IMI herbicide resistance were developed and released for the development of commercial resistant hybrids (Al-Khatib and Miller, 2000). The commercial IMI tolerance trait Imisun that arose from that introgression work had a great impact in sunflower breeding, not only because of the extensive list of weeds controlled in postemergence by IMI herbicides, but also because they proved to be highly efficient in controlling sunflower broomrape (Alonso et al., 1998). Consequently, IMI-tolerant sunflowers, currently commercialized under the Clearfield trademark, have gained a market share very quickly once the trait has been incorporated into performing hybrids by most of the sunflower seed companies. The inheritance of Imisun was found to be controlled by one gene Imr 1, also known as Ahasl1-1, exhibiting partial dominance, which is affected by a second gene Imr2 with modifier or enhancer effect in some genetic backgrounds (Bruniard and Miller, 2001). To produce Imisun sunflower hybrids that express commercial tolerance levels to IMI herbicides, both genes need to be in homozygous state. A new IMI-resistant trait initially designated CLHA-plus and later CLPlus was developed by mutagenesis and selection with imazapyr (Sala et al., 2008). Molecular and genetic studies concluded that CLPlus is controlled by the expression of the partially dominant allele Ahasl1-3, which is different from Ahasl1-1. Both of them are allelic variants of locus Ahasl1, one of the three genes coding for the AHAS catalytic subunits in sunflower (Sala et al., 2008). Lines and hybrids carrying the CLPlus mutation have better tolerance to IMI herbi- 
cides and commercial tolerance levels can be achieved incorporating CLPlus in only one parent of a Clearfield hybrid, thus allowing more rapid development of the hybrid. The allele Ahasl1-3 has been found to be dominant over Ahasl1-1 (Sala et al., 2012). New sources of resistance to IMI herbicides have been recently identified in populations of wild $H$. annuus and $H$. argophylus (Christov et al., 2010).

\section{CONCLUSIONS AND FUTURE PROSPECTS}

Sunflower broomrape continues to be one of the most serious production constraints in many sunflower-producing countries around the world after more than a century. Race-specific dominant genes have been considered to be the ideal source of resistance for single-cross hybrid breeding by seed companies, because they only need to be incorporated into one of the parents, but their extensive use for this purpose has contributed to the rapid evolution of new virulent races. This requires a continuous search for new resistance sources. Wild Helianthus species constitute the major source of resistance genes conferring resistance to new virulent races, but cultivated germplasms have also provided valuable sources of resistance. Most of the resistant sources have been found to be controlled by major genes (vertical resistance), although quantitative (horizontal) resistance has also been reported. With this situation, a set of integrated strategies including the use of herbicide-tolerant cultivars to control broomrape and the development of more durable genetic resistance is needed. Novel approaches to improve durability of broomrape resistance include the combination of vertical and horizontal resistance mechanisms assisted by the use of molecular markers. Reproducible molecular markers for accurately identifying $O$. cumana races also need to be developed. The combination of such strategies is expected to contribute to the improvement of sunflower performance in areas infested by broomrape.

\section{ACKNOWLEDGEMENTS}

The authors wish to thank the organizers of the $18^{\text {th }}$ International Sunflower Conference in Mar del Plata \& Balcarce, Argentina for their invitation to give this Plenary Lecture.

\section{REFERENCES}

Akhtouch, B., Muñoz-Ruz, J., Melero-Vara, J.M., Fernández-Martínez, J.M. and Domínguez, J., 2002. Inheritance of resistance to race $\mathrm{F}$ of broomrape (Orobanche cumana Wallr.) in sunflower lines of different origin. Plant Breeding 121: 266-269.

Al-Khatib, K., and Miller, J.F., 2000. Registration of four genetic stocks of sunflower resistant to imidazolinone herbicides. Crop Sci. 40: 869-870.

Al-Khatib, K., Baumgartner, J.R., Peterson, D.E. and Currie, R.S., 1998. Imazethapyr resistance in common sunflower (Helianthus annuus). Weed Sci. 46: 403-407. 
Alonso, L.C., Fernández-Escobar, J., López, G., Rodríguez-Ojeda, M. and Sallago, F., 1996. New highly virulent sunflower broomrape (Orobanche cernua Loefl.) pathotype in Spain. In: Advances in Parasitic Plant Research. Proc. $6^{\text {th }}$ Int. Symp. Parasitic Weeds. Córdoba, Spain. Pp. 639-644.

Alonso, L.C., Rodríguez-Ojeda, M.I., Fernández-Escobar, J. and Lopez-Calero, G., 1998. Chemical control of broomrape (Orobanche cernua Loefl.) in sunflower (Helianthus annuus L.) resistant to imazethapyr herbicide. Helia 21: 45-54.

Bruniard, J.M., and Miller, J.F., 2001. Inheritance of imidazolinone-herbicide resistance in sunflower. Helia 24: 11-16.

Christov, M., Hristova-Cherbadzi, M., Encheva, V., Sindrova, P., Kiryakov, I., Valkova, D., Sabev, G. and Batchvarova, R., 2010. Creating new sunflower forms and lines, resistant to diseases, the broomrape parasite. In: Proc. Int. Symp. "Sunflower breeding on Resistance to diseases” Krasnodar, Russia. Int. Sunfl. Assoc., Paris, France. Pp. 72-84.

Domínguez, J., 1996a. Estimating effects on yield and other agronomic parameters in sunflower hybrids infested with the new races of sunflower broomrape. In: Proc. Symposium on Disease Tolerance in Sunflower, Beijing, China, Int. Sunfl. Assoc., Paris. Pp. 118-123.

Domínguez, J., 1996b. R-41, a sunflower restorer inbred line, carrying two genes for resistance against a highly virulent Spanish population of Orobanche cernua. Plant Breeding 115: 203-204.

Echevarría-Zomeño, S., Pérez-de-Luque, A., Jorrín, J. and Maldonado, A., 2006. Pre-haustorial resistance to broomrape (Orobanche cumana) in sunflower (Helianthus annuus): Cytochemical studies. J. Exp. Bot. 57: 4189-4200.

Fernández-Escobar, J., Rodríguez-Ojeda, M.I., Fernández-Martínez, J.M. and Alonso, L.C., 2009. Sunflower broomrape (Orobanche cumana Wallr.) in Castilla-León, a traditionally non-broomrape infested area in Northern Spain. Helia 32(51): 57-64.

Fernández-Martínez, J.M., Domínguez, J., Pérez-Vich, B. and Velasco, L., 2008. Update on breeding for resistance to sunflower broomrape. Helia 31(48): 73-84.

Fernández-Martínez, J.M., Melero-Vara, J.M., Muñoz-Ruz, J., Ruso, J. and Domínguez, J., 2000. Selection of wild and cultivated sunflower for resistance to a new broomrape race that overcomes resistance to Or $_{5}$ gene. Crop Sci. 40: 550-555.

Gagne, G., Roeckel-Drevet, P., Grezes-Besset, B., Shindrova, P., Ivanov, P., Grand-Ravel, C., Vear, F., Tourvieille de Labrouhe, D., Charmet, G. and Nicolas, P., 1998. Study of the variability and evolution of Orobanche cumana populations infesting sunflower in different European countries. Theor. Appl. Genet. 96: 1216-1222.

Hassan, E.A.R.S., Hoeft, E. and Tulsieram, L., 2011. Genetic markers for Orobanche resistance in sunflower. United States Patent \# 7872170.

Jan, C.C., and Fernández-Martínez, J.M. 2002. Interspecific hybridization, gene transfer, and the development of resistance to broomrape race F in Spain. Helia 25(36): 123-136.

Jouffret, P., and Lecomte, V., 2010. Orobanche sur Tournesol. Un parasite en Extension. Lettre d'Informations Regionales CETIOM, Zone Sud. http://www.cetiom.fr, accessed December 9, 2011.

Labrousse, P., Arnaud, M.C., Serieys, H., Bervillé, A. and Thalouan, P., 2001. Several mechanisms are involved in resistance of Helianthus to Orobanche cumana Wallr. Ann. Bot. 88: 859-868.

Lu, Y.H., Melero-Vara, J.M., García-Tejada, J.A. and Blanchard, P., 2000. Development of SCAR markers linked to the gene $\mathrm{Or}_{5}$ conferring resistance to broomrape (Orobanche cumana Wallr.) in sunflower. Theor. Appl. Genet. 100: 625-632.

Molinero-Ruiz, M.L., Pérez-Vich, B., Pineda-Martos, R. and Melero-Vara, J.M., 2008. Indigenous highly virulent accessions of the sunflower root parasitic weed Orobanche cumana. Weed Res. 48: 169-178.

Păcureanu-Joita, M., Fernández-Martinez, J.M., Sava, E. and S. Raranciuc, S., 2009. Broomrape (Orobanche cumana Wallr.), the most important parasite in sunflower. Analele I.N.C.D.A. Fundulea 77: 49-56.

Pérez-de-Luque, A., Fondevilla, S., Pérez-Vich, B., Aly, R., Thoiron, S., Simier, P., Castillejo, M.A., Fernández-Martínez, J.M., Jorrín, J., Rubiales, D. and Delavault, P., 2009. Understanding Orobanche and Phelipanche-host plant interaction and developing resistance. Weed Res. 49(S1): 8-22.

Pérez-Vich, B., Akhtouch, B., Muñoz-Ruz, J., Fernández-Martínez, J.M. and Jan, C.C., 2002. Inheritance of resistance to a highly virulent race $\mathrm{F}$ of Orobanche cumana Wallr. in a sunflower line derived from interspecific amphiploids. Helia 25(36): 137-144. 
Pérez-Vich, B., Akhtouch, B., Knapp, S.J., Leon, A.J., Velasco, V., J.M. Fernández-Martínez, J.M. and Berry, S.T., 2004. Quantitative trait loci for broomrape (Orobanche cumana Wallr.) resistance. Theor. Appl. Genet. 109: 92-102.

Radwan, O., Gandhi, S., Heesacker, A., Whitaker, B., Taylor, C., Plocik, A., Kesseli, R., Kozik, A., Michelmore, R.W and Knapp, S.J., 2008. Genetic diversity and genomic distribution of homologs encoding NBS-LRR disease resistance proteins in sunflower. Mol. Genet. Genomics 280: 111-125.

Rodríguez-Ojeda, M.I., Fernández-Escobar, J. and Alonso, L.C., 2001. Sunflower inbred line (KI-374) carrying two recessive genes for resistance against a highly virulent Spanish population of Orobanche cernua Loefl. / O. cumana Wallr. race F. In: Proc. $7^{\text {th }}$ Int. Parasitic Weed Symposium, Nantes, France. Pp. 208-211

Rodríguez-Ojeda, M.I., Pérez-Vich, B., Alonso, L.C. and J. Fernández-Escobar, J., 2010. The influence of flowering plant isolation on seed production and seed quality in Orobanche cumana. Weed Res. 50: 515-518.

Rodríguez-Ojeda, M.I., Velasco, L., Alonso, L.C., Fernández-Escobar, J. and Pérez-Vich, B., 2011. Inheritance of the unpigmented plant trait in Orobanche cumana. Weed Res. 51: 151-156.

Rodríguez-Ojeda, M.I., Fernández-Martínez, J.M., Velasco, L., Pérez-Vich, B., 2012. Extent of cross-fertilization in Orobanche cumana Wallr. Biol. Plantarum (in press).

Sala, C.A., Bulos, M., Echarte, M., Whitt, S.R. and Ascenzi, R., 2008. Molecular and biochemical characterization of an induced mutation conferring imidazolinone resistance in sunflower. Theor. Appl. Genet. 118: 105-112.

Sala, C.A., Bulos, M., Altieri, E. and Weston, B., 2012. Response to imazapyr and dominance relationships of two imidazolinone-tolerant alleles at the Ahasl1 locus of sunflower. Theor. Appl. Genet. 124: 385-396.

Škorić, D., Păcureanu-Joita, M. and Sava, E., 2010. Sunflower breeding for resistance to broomrape (Orobanche cumana Wallr.). Analele I.N.C.D.A. Fundulea 78: 63-79.

Sukno, S., Melero-Vara, J.M. and Fernández-Martínez, J.M., 1999. Inheritance of resistance to Orobanche cernua Loefl. in six sunflower lines. Crop Sci. 39: 674-678.

Tan, S., Evans, R.R., Dahmer, M.L., Singh, B.K. and Shaner, D.L., 2005. Imidazolinone-tolerant crops: history, current status and future. Pest Manag. Sci. 61: 246-257.

Tang, S., Heesacher, A., Kishore, V.K., Fernández, A., Sadik, E.S., Cole, G. and S.J. Knapp, S.J., 2003. Genetic mapping of the $\mathrm{Or}_{5}$ gene for resistance to Orobanche race $\mathrm{E}$ in sunflower. Crop Sci. 43: 1021-1028.

Velasco, L., Pérez-Vich, B., Jan, C.C. and Fernández-Martínez, J.M., 2006. Inheritance of resistance to broomrape (Orobanche cumana Wallr.) race $\mathrm{F}$ in a sunflower line carrying resistance genes from wild sunflower species. Plant Breeding 126: 67-71.

Velasco, L., Pérez-Vich, B., Yassein, A.A.M., Jan, C.C. and Fernández-Martínez, J.M., 2012. Inheritance of resistance to sunflower broomrape (Orobanche cumana Wallr.) in a interspecific cross between Helianthus annuus and Helianthus debilis subsp. tardiflorus. Plant Breeding 131: 220-221.

Vrânceanu, A.V., Tudor, V.A., Stoenescu, F.M. and Pirvu, N., 1980. Virulence groups of Orobanche cumana Wallr. differential hosts and resistance sources and genes in sunflower. In: Proc. $9^{\text {th }}$ Int. Sunfl. Conf., Torremolinos, Spain. Int. Sunfl. Assoc., Paris. Pp. 74-80.

Vrânceanu, A.V., Pirvu, N., Stoenescu, F., and Pacureanu, M., 1986. Some aspects of the interaction Helianthus annuus L. / Orobanche cumana Wallr. and its implications in sunflower breeding. In: S.J. Ter Borg (ed.), Workshop on Biology and Control of Orobanche. Wageningen, The Netherlands. Pp. 181-188. 


\title{
AVANCES EN LA INVESTIGACIÓN EN MEJORAMIENTO PARA LA RESISTENCIA AL JOPO
}

\author{
RESUMEN
}

El jopo de girasol (Orobanche cumana Wallr.) es una angiosperma parásita considerada como uno de los más graves obstáculos para el cultivo de girasol en muchos países productores. Históricamente, los mejoradores de girasol han tenido éxito en el desarrollo de cultivares resistentes a este parásito, si bien la introducción de nuevas fuentes de resistencia ha ido frecuentemente seguida por la aparición de nuevas razas patogénicas que superaban la resistencia. La presente revisión examina los principales logros en este campo que se han llevado a cabo durante las últimas décadas, centrándose en los avances más recientes. En los últimos años, varios grupos de investigación han realizado contribuciones relevantes en la mejora para resistencia y en el desarrollo de estrategias de control. Tras la identificación y caracterización de nuevas razas virulentas, se han desarrollado nuevas fuentes y mecanismos de resistencia, que han sido caracterizados a nivel genético y molecular. Se han realizado asimismo importantes contribuciones al conocimiento de la biología y la genética del parásito, que ayudarán a comprender la dinámica de las poblaciones y la evolución de las razas de jopo. Se han llevado a cabo también importantes avances en el uso de híbridos resistentes a imidazolinonas (IMI) como un método alternativo de control. La mayoría de los estudios sobre la mejora de girasol para resistencia a $O$. cumana se han centrado hasta ahora en la planta huésped, pero, a pesar de los recientes avances, se conoce poco acerca de aspectos importantes del parásito como su sistema de reproducción y la genética de la virulencia. Un problema no resuelto es la incertidumbre existente en la denominación de razas y genes de resistencia identificados en diferentes países. Existe por tanto necesidad de cooperación internacional en esta área, utilizando líneas diferenciales comunes y herramientas moleculares. Se hace hincapié en la necesidad de un enfoque multidisciplinario que va desde el estudio de los mecanismos subyacentes a la resistencia de la planta huésped a la biología de la reproducción y la genética de caracteres relacionados con el parasitismo de O. cumana. La combinación de estrategias a largo plazo que incluyan el sistema huésped-parásito en su conjunto y la integración de los enfoques clásicos y moleculares contribuirán al desarrollo de fuentes de resistencia más duraderas y en consecuencia un mayor rendimiento del cultivo de girasol en áreas infestadas por jopo.

Palabras clave: razas de jopo, la resistencia genética, la tolerancia a herbicidas, Helianthus annuus, Orobanche cumana, girasol 